\title{
BALANCING INVESTOR PROTECTION WITH A STATE'S REGULATORY AUTONOMY IN THE AMENDED SADC FIP
}

\author{
Mmiselo Freedom Qumba \\ LLB LLM \\ Lecturer, University of the Free State
}

\section{SUMMARY}

This article focuses on the 2016 Amended Annex 1 to the Southern African Development Community (SADC) Finance and Investment Protocol (FIP) (the Amended Annex), which entered into force on 22 August 2017. It aims at a comprehensive assessment of the adequacy of the Amended Annex in balancing investor protection with SADC member states' quest for domestic policy space in the content of the treaty provisions. Prior to the amendment, the 2006 SADC FIP contained clauses that were considered challenging in the old international investment agreements (IIAs) - such as broad definitions of "investor" and "investment", provision for international arbitration as a recourse, and according foreign investors fair and equitable treatment (FET) and most favoured nation (MFN) treatment. The challenges associated with bilateral investment treaties (BITs) (especially investor-state dispute settlement (ISDS) mechanisms, restrictions on sovereign policy space and regulatory autonomy) necessitated a review by the SADC member states of the 2006 SADC FIP. The purpose of this article is to reflect on the implications of the 2016 Amended Annex 1 to the SADC FIP with a view to finding a balance between protection enjoyed by investors and the host states' right to regulate. The article adopts a comparative international law approach, which is usefu in order better to understand a SADC member country's approach to foreign investment protection.

\section{INTRODUCTION}

This article focuses on the 2016 Amended Annex 1 to the SADC Finance and Investment Protocol (FIP) (the Amended Annex), which entered into force on 22 August 2017. It aims at a comprehensive assessment of the adequacy of the Amended Annex in balancing investor protection with SADC member states' quest for domestic policy space in the content of the treaty provisions. ${ }^{1}$ Prior to the amendment, the 2006 SADC FIP had several

Southern African Development Community "Agreement Amending Annex 1 (Co-Operation on Investment) of the Protocol on Finance and Investment" Adopted: 31/08/2016; EIF 24/08/2017 (New Annex 1) https://www.sadc.int/files/7114/9500/6315/ Agreement Amending Annex 1 - Cooperation on investment - on the Protocol on Finance_Investment_-_English_-_2016.pdf (accessed 2020-09-12). The current SĀDC member states are Angola, Botswana, the Democratic Republic of Congo, Lesotho, 
clauses that were regarded as pro-foreign investor and as problematic in the old-generation international investment agreements (IIAs) - such as those providing broad definitions of "investor" and "investment", and according foreign investors fair and equitable treatment (FET), national treatment and most favoured nation (MFN) treatment, as well as investor-state dispute settlement (ISDS) clauses. ${ }^{2}$ The challenges associated with bilateral investment treaties (BITs) (especially ISDS mechanisms, restrictions on sovereign policy space and regulatory autonomy) necessitated a review by SADC member states of the 2006 SADC FIP. ${ }^{3}$ Most fundamentally, the 2006 SADC FIP became a highly controversial instrument as a number of investment claims were filed against SADC member states.

The broad scope of the 2006 SADC FIP's substantive provisions led many tribunals to deem it applicable to all foreign investors, as well as domestic investors in SADC member states. ${ }^{4}$ Based on experience with ISDS, SADC member states raised serious concerns about the settlement of investorstate disputes by international arbitration. ${ }^{5}$ These concerns included, inter alia, lack of legitimacy and transparency, huge costs of arbitration and arbitral awards, inconsistent and erroneous decisions, and forum shopping. In addition, SADC member states were concerned that the Annex's ambiguous provisions (such as MFN, expropriation clauses and FET standards) were likely to give very wide interpretative discretion to international tribunals. These concerns, together with ongoing legitimacy concerns over ISDS, triggered the treaty amendment and resulted in the recognition that signatories to the 2006 SADC FIP with valid BITs in place may face investment disputes initiated using the old FIP. Notably, the motivation for the treaty amendment is clearly spelt out in the Preamble to the 2016 Amended Annex of the SADC FIP, namely that the provisions of the 2006 SADC FIP may have unintended consequences for SADC member states. The drafters of the 2016 SADC FIP also noted that some of the provisions of the 2006 SADC FIP failed to balance investor protection adequately with the development of policy space for host states. They recognised that there was a need to amend the 2006 Annex 1 of the SADC FIP in order to address its shortcomings. ${ }^{6}$

It is against this backdrop that SADC member states decided to amend the Annex. While the amended 2016 SADC FIP has already drawn comments, this article adds value to the existing literature by carrying out a

Madagascar, Malawi, Mauritius, Mozambique, Namibia, the Seychelles, South Africa, Swaziland, the United Republic of Tanzania, Zambia and Zimbabwe.

2 Chidede "Amendments of Annex 1 to the SADC Finance and Investment Protocol: Are They in Force Yet?" https://www.tralac.org/discussions/article/11875-amendments-of-annex-1-tothe-sadc-finance-and-investment-protocol-are-they-in-force-yet.html (accessed 2020-0721).

3 Chidede https://www.tralac.org/discussions/article/11875-amendments-of-annex-1-to-thesadc-finance-and-investment-protocol-are-they-in-force-yet.html 11.

4 The Burmilla Trust, The Josias Van Zyl Family Trust and Josias Van Zyl $v$ The Kingdom of Lesotho (PCA Case No. 2016/21).

5 Parliamentary Monitoring Group "Summary of the Key Amendments to Annex of the SADC Finance and Investment Protocol" (2016) http://pmg.org.za/files/150922summary.pdf (accessed 2020-09-12).

6 Kondo "A Comparison With Analysis of the SADC FIP Before and After Its Amendment" 2017 Potchefstroom Electronic Law Journal 4. 
comprehensive and detailed analysis of the Amended Annex, especially from the standpoint of two key objectives that the SADC member government claims the Amended Annex achieves. First, SADC member countries claim that the purpose of the Amended Annex is to provide "appropriate protection to foreign investors in the SADC region, while maintaining a balance between investors' rights and the government's obligations." The South African government told Parliament the

"new Amended SADC FIP text is aimed at providing appropriate protection to foreign investors in SADC Member States and SADC investors in the foreign country, in the light of relevant international precedents and practices, while maintaining a balance between the rights of the investors and the obligations of the Government."

Secondly, it is claimed that the Amended Annex aims to make the treaty provisions more precise so as to minimise arbitral discretion.

The purpose of this article is to reflect on the implications of the Amended Annex from the standpoint of whether a balance has been found (in the Amended Annex) between the protection enjoyed by investors on the one hand, and a host state's right to regulate on the other. The article does this by adopting a comparative international law approach. A comparative analysis is useful in order better to understand a SADC member country's approach to foreign investment protection. The article compares, on the one hand, the Amended Annex to modern regional treaty practice (for example, the Pan-African Investment Code (PAIC), investment chapters in comprehensive free trade agreements (FTAs) such as the Trans-Pacific Partnership (TPP), ${ }^{9}$ and comprehensive economic and trade agreements (CETAs) between the European Union and Canada). ${ }^{10}$ Some of these international investment agreements (IIAs) contain innovative provisions and it would be useful to provide insights into whether SADC member countries' respective approaches differ from the current practice of other countries and regions. It also compares the Amended Annex to SADC member countries' investment treaties and domestic laws in order to gain a clear picture of how the Amended Annex builds upon the investment regulatory framework of SADC member countries' investment regimes, and it examines its limitations in achieving the same.

7 SADC https://www.sadc.int/files/7114/9500/6315/Agreement_Amending_Annex_1_Cooperation on investment - on the Protocol on Finance Investment - English 2016.pdf Preamb̄le.

8 Parliamentary monitoring Group "The African Continental Free Trade Area, SADC Protocol on Finance and Investment, Copy Amendment Bill, Clauses to be advertised, BRRR" https://pmg.org.za/committee-meeting/27213/ (accessed 2021-12-01).

9 Office of the United States Trade Representative "Trans-Pacific Partnership Agreement" https://ustr.gov/trade-agreements/free-trade-agreements/trans-pacific-partnership/tpp-fulltext (accessed 2020-08-13).

10 UNCTAD Investment Policy Hub "Comprehensive Economic and Trade Agreements (CETA) between the European Union and Canada" https://investmentpolicy.unctad.org/ international-investment-agreements/treaties/treaties-with-investment-provisions/3546/ canada---eu-ceta-2016- (accessed 2020-08-14). 


\section{THE PREAMBLE}

The primary significance of a preamble is its influence on how IIAs will be interpreted in the event of a dispute between investor and host state. ${ }^{11}$ In contemporary treaty drafting, there are broader investment treaty objectives that have become prevalent, including, prominently, the objective of sustainable development. ${ }^{12}$ In the SADC region, sustainable development imperatives and responsible investment are crucial, given the developmental challenges involving economic, social and environmental issues with which the region still grapples. In the same vein, in terms of the 2016 SADC FIP Preamble, SADC member countries are committed to achieving economic growth and sustainable development through regional integration and by working through investment promotion agencies in the region. ${ }^{13}$ They recognise the significant role played by investment in advancing productive capacity and its contribution to the economic growth of a country and sustainable development and linkages between trade and investment. In drafting the Preamble of the 2016 SADC FIP, a clear link between the importance of investment and sustainable development has been made. ${ }^{14}$

By comparison, the Preamble to the continent-wide Pan-African Investment Code (PAIC) ${ }^{15}$ and the SADC Model BIT ${ }^{16}$ also capture the essence of promoting and encouraging investment opportunities that enhance sustainable development within the territories of member states. Specifically, sustainable development objectives permeate the provisions of PAIC and promote sustainable development-oriented investments. More importantly, the required kind of investment is that which has spill-over effects on job creation, promotion of technology transfers and support for long-term economic growth, and which makes a significant contribution in the fight against poverty. The member states party to the 2016 SADC FIP recognise that without sustainable development policies, which have become a prevailing norm in treaty drafting, the SADC region will continue to be marginalised. Notably, the protection of investors has not been given priority as a significant objective in the Preamble of the 2016 SADC FIP. Instead, the objectives of the treaty are to achieve an overall balance between the rights and obligations among states and investors. ${ }^{17}$ Indeed,

11 Dolzer and Schreuer Principles of International Investment Law (2013) 201.

12 UNCTAD "Investment Policy Framework for Sustainable Development" http://unctad.org/fr/PublicationsLibrary/diaepcb2012d5_en.pdf (accessed 2020-08-13).

13 Southern African Development Community https://www.sadc.int/files/7114/9500/6315/ Agreement_Amending_Annex_1_-_Cooperation_on_investment_-_on_the_Protocol_on_ Finance_Investment_-_English_-_2016.pdf Preamble.

14 Mbengue and Schacherer "The Africanization of International Investment Law: The PanAfrican Investment Code and Reform of the International Investment Regime" 2017 The Journal of World Investment and Trade 418.

15 African Union Commission "Draft Pan African Investment Code PAIC" https://au.int/sites/default/files/documents/32844-doc-draft_pan-african_investment_code_ december_2016_en.pdf (accessed 2020-8-15) Preamble.

16 SADC "The Southern African Development Community (SADC) Model Bilateral Investment Treaty Template" Adopted: 2012. https://www.iisd.org/itn/wpcontent/uploads/2012/10/SADC-Model-BIT-Template-Final.pdf (accessed 2020-08-16) Model Preamble. The model BIT is not binding and is not intended to be binding.

17 Ibid. 
SADC member states were concerned with the low levels of investment in the region. Accordingly, SADC member states also aim to create employment opportunities, improve living standards, enhance attractiveness of the region as an investment destination through cooperation among the investment regional agencies and by creating a conducive investment environment. ${ }^{18}$

\section{DEFINITION OF INVESTMENT}

Given the contentious nature of the investment definition, the drafting of the clause dealing with the scope of what constitutes an investment was critical for SADC member states. ${ }^{19}$ In departing from a pro-investor investment definition, SADC member countries reasoned that the previous 2006 SADC FIP definition of "investment" was asset-based, too broad and lacking in precision. They noted that an asset-based definition was known for being too wide, often covering a non-exhaustive list of assets regardless of whether such assets form part of a functioning business operating in the host state where an investment has been made. ${ }^{20}$ The drafters of the Amended Annex decided to replace the asset-based definition with an enterprise-based definition. Hence, the Amended Annex states that an investment means

"an enterprise within the territory of the state party which is established, acquired or expanded by an investor, including through the constitution, maintenance or acquisition of shares, debentures or other ownership instruments of such an enterprise." 21

In addition, the assets of the enterprise in the Amended Annex are included among the covered assets of the investor in an open and indicative list of assets. ${ }^{22}$

In this regard, in 2016, SADC followed the correct trend since PAIC has also opted for a similar approach. ${ }^{23}$ In many jurisdictions, such as Brazil, ${ }^{24}$ India, ${ }^{25}$ and recently in the Nigeria-Morocco BIT, ${ }^{26}$ a similar approach has

18 Kondo 2017 Potchefstroom Electronic Law Journal 5.

19 Qumba "Assessing African Regional Investment Instrument and Investor-State Dispute Settlement" 2021 International \& Comparative Law Quarterly 199.

20 Kondo 2017 Potchefstroom Electronic Law Journal 5.

21 Art 1 of the Amended Annex https://www.sadc.int/files/7114/9500/6315/Agreement Amending_Annex_1_-_Cooperation_on_investment_-_on_the_Protocol_on_Finance_ Investment_-_English_-_2016.pdf (accessed 2021-12-01).

22 Ibid.

23 African Union Commission https://au.int/sites/default/files/documents/32844-doc-draft_panafrican investment code december 2016 en.pdf.

24 UNCTAD Investment Policy Hub "Investment Cooperation and Facilitation Treaty Between the Federative Republic of Brazil and the Republic of India" https://investmentpolicy.unctad.org/international-investment-agreements/treaty-files/5912/ download (accessed 2020-08-14) art 2(4).

25 Law Commission of India Report 260 "Analysis of the 2015 Draft Indian Model Bilateral Investment Treaty August 2015" http://1awcommissionofindia.nic.in/reports/Report260.pdf (accessed 2020-08-18).

26 UNCTAD Investment Policy Hub "Reciprocal Investment Promotion and Protection Agreement Between the Government of the Kingdom of Morocco and the Government of the Federal Republic of Nigeria" https://investmentpolicy.unctad.org/internationalinvestment-agreements/treaty-files/5409/download (accessed 2020-08-15). 
been adopted. The SADC Model BIT also adopts the enterprise-based definitions as being the most beneficial option for the purposes of sustainable development. ${ }^{27}$ In general, the acquisition and establishment of an enterprise is viewed as more likely to generate long-term interests in the host state. Therefore, the drafters of the Amended Annex opted for an investment definition that encourages stimulation of broad-based economic growth and generates the required linkage necessary to make foreign direct investment work for sustainable development. ${ }^{28}$ This approach is in contrast to an open-ended investment definition, which could be extended to investments tainted by wilful misrepresentation, bad faith or fraud, or which constitute a violation of national or international public policy owing to broad interpretations of what constituted investments under the old generation BITs. ${ }^{29}$

The agreement of the SADC FIP excludes a series of assets in the scope of its investment definition. ${ }^{30}$ Notably, it excludes portfolio investment altogether. There may be good policy reasons for excluding portfolio investments from the definition of investment; they are merely speculative investments initiated without any intention to hold on to them or to contribute towards the economic development of the host state. ${ }^{31}$ It also excludes investments that arise purely from commercial contracts. Most other treaties also exclude certain categories. The most typical are the exclusion of pure commercial contract claims by CETA, ${ }^{32}$ the exclusion of loans issued by one party to another party and an order or judgment entered in a judicial or administrative action under the TPP. ${ }^{33}$ Similarly, PAIC excludes portfolio investments but, unlike others, PAIC excludes investments in any sector that is sensitive to the host state's development and investments that would have an adverse impact on its economy. ${ }^{34}$ In safeguarding domestic policy space by excluding certain categories of entity from its investment definition, the 2016 SADC FIP follows the contemporary trends.

The investment definition in the treaty should be drafted so as to indicate a strong relationship between covered investments and development of the host state's economy. To do this, the author suggests that the Amended

27 SADC https://www.iisd.org/itn/wp-content/uploads/2012/10/SADC-Model-BIT-TemplateFinal.pdf art 2.

28 SADC https://www.sadc.int/files/7114/9500/6315/Agreement_Amending_Annex_1_Cooperation on investment_- on the Protocol on Finance Investment_- English _ 2016.pdf Art 1(2).

29 Phoenix Action v Czech Republic, Phoenix Action Ltd v Czech Republic ICSID Case No. ARB/06/5.

30 SADC https://www.sadc.int/files/7114/9500/6315/Agreement_Amending_Annex_1_Cooperation_on_investment_-_on_the_Protocol_on_Finance_Investment_-_English_2016.pdf.

31 Rajput "Safeguarding India's Regulatory Autonomy: Analysis of the New Model Bilateral Investment Treaty" 2017 Manchester Journal of International Economic Law 284.

32 UNCTAD Investment Policy Hub https://investmentpolicy.unctad.org/internationalinvestment-agreements/treaties/treaties-with-investment-provisions/3546/canada---eu-ceta2016- Art 8(1).

33 Office of the United States Trade Representative https://ustr.gov/trade-agreements/freetrade-agreements/trans-pacific-partnership/tpp-full-text Art (9)(1).

34 African Union Commission https://au.int/sites/default/files/documents/32844-doc-draft_panafrican_investment_code_december_2016_en.pdf art(4)(i)-(ii). 
Annex could have incorporated what is known as the Salini test ${ }^{35}$ in its definition of covered investment. The investment definition could have required the following characteristics:

"(1) the commitment of capital or other resources, (2) the expectation of gain or profit, (3) the assumption of risk, and (4) a significant contribution to the host State's economic development." 36

The suggestion comports with today's treaty practice. The presence of these objective elements under the Salini test ensures that the foreign investor has made an actual investment in good faith and is contributing to the development of the host state's economy. ${ }^{37}$ However, the inclusion of the Salini test in the covered investment varies from jurisdiction to jurisdiction. The Nigeria-Morocco BIT, ${ }^{38}$ PAIC and the Indian Model BIT ${ }^{39}$ contain all four elements of the Salini test, while the US Model BIT, ${ }^{40}$ like CETA and TPP, excludes the element involving a significant contribution to the host state's economic development.

\section{DEFINITION OF AN INVESTOR}

The Amended Annex limits the definition of an investor. An investor is defined as

"a natural or a juridical person of another State Party, in accordance with the

laws and regulations of the State Party in which the investment is made." 41

This narrow definition of an investor means that the Amended Annex only covers investors that originate from SADC member countries. Investors that originate outside the SADC region are no longer protected under the Amended Annex. The way the investor is defined presents a significant limitation to the protection of foreign investors, usually the major investors in SADC member countries. For this reason, it has been argued that the investor definition "limits the usefulness" of the Amended Annex. ${ }^{42}$

In addition, the investor definition has been drafted in sharp contrast to the recommendation by South Africa in its travaux préparatoires, in which it

35 Salini Costruttori SpA and Italstrade SpA v Kingdom of Morocco ICSID Case No. ARB/00/4, Decision on Jurisdiction (23 July 2001) par 53.

36 Grabowski "The Definition of Investment Under the ICSID Convention: A Defense of Salini" 2014 Chicago Journal of International Law 291.

37 Ngobeni "Do the SALINI Criteria Apply to the Definition of an Investment Provided in Annex 1 of the 2006 and 2016 SADC Protocol on Finance and Investment? An Assessment" 2020 Potchefstroom Electronic Law Journal 6.

38 UNCTAD Investment Policy Hub https://investmentpolicy.unctad.org/internationalinvestment-agreements/treaty-files/5409/download Art 1(3).

39 Law Commission of India Report 260 http://1awcommissionofindia.nic.in/reports/ Report260.pdf (accessed 2020-08-18).

40 Office of the United States Trade Representative "US Model BIT" (2012) https://ustr.gov/sites/default/files/BIT\%20text\%20 for\%20ACIEP\%20Meeting.pdf (accessed 2020-08-17) Art 1.

41 SADC https://www.sadc.int/files/7114/9500/6315/Agreement_Amending_Annex_1__Cooperation_on_investment_-_on_the_Protocol_on_Finance_Investment_-_English_2016.pdf Art 1(2).

42 Kondo 2017 Potchefstroom Electronic Law Journal 9. 
suggested that all foreign investments from any state be covered, subject to the condition that a dispute between an investor and a member state be adjudicated in terms of the domestic law of such a state. ${ }^{43}$ Furthermore, the definition does not resolve outstanding issues in the previous definition on the treatment of dual nationals and companies managed in effect in other jurisdictions. Therefore, a juristic person owned or controlled by foreign nationals may not qualify as an investor under the Amended Annex regardless of its substantial business activity in a member state in which it is duly constituted or organised. ${ }^{44}$ The definition of investor therefore defeats the purpose of the Amended Annex, which is to provide a balance or preserve the interests of investors and states alike. The writer suggests that a more sensible definition of investor could have been drafted in the following terms:

"Investor means any national, company or enterprise of a Member State or a national, company or enterprise from any other country that has invested or has made investments in a Member State."

Most fundamentally, the suggested definition of investor could have addressed the notion of a juristic person, given the enterprise-based definition in the Amended Annex. With regard to juristic persons, contemporary treaty drafters base their definitions on three concepts to determine an enterprise's nationality: control, incorporation and social seat. ${ }^{45}$ A treaty that defines the nationality of a legal entity solely on the basis of the place of incorporation has potentially the largest coverage. The most recent treaties, such as the TPP and the Indian Model BIT, often require that the juristic person's nationality not only be determined by the place of incorporation but also that it should have a "substantial business activity" in the home state. ${ }^{46}$ PAIC builds on the concept of the place of incorporation by requiring substantial business activity in the member state in which the enterprise or company is located. ${ }^{47}$

\section{NATIONAL TREATMENT}

The Amended Annex adopts a slightly new approach to the relative standard of national treatment protection. It must be pointed out that the general tenor of the treatment standard is narrow in comparison to prior BITs and the 2006 SADC FIP. The Amended Annex uses two methodologies for enhancing regulatory autonomy and limiting investor protection: removal of controversial treatment standards, as discussed below, and narrowing existing national treatment standard. It requires state parties to accord no less favourable treatment to investors and their investments than the

43 Parliamentary Monitoring Group http://pmg.org.za/files/150922summary.pdf (accessed 2020-09-12).

44 UNCTAD "Investment Policy Framework for Sustainable Development" (2015) https://unctad.org/system/files/official-document/diaepcb2015d5_en.pdf (accessed 2020-0820).

45 Mbengue and Schacherer 2017 The Journal of World Investment and Trade 425.

46 Ranjan and Anand "The 2016 Model Indian Bilateral Investment Treaty: A Critical Deconstruction" 2017 North-Western Journal of International Law \& Business 17.

47 Mbengue and Schacherer 2017 The Journal of World Investment and Trade 425. 
treatment it accords, in like circumstances, to its own domestic investors with respect to the management, operation and disposition of investments in its territory. ${ }^{48}$ In terms of article 6(2), an express provision is made regarding the circumstances that should be considered when assessing the question of "like circumstances". 49 Investment chapters in earlier BITs and FTAs, such as the North American Free Trade Agreement (NAFTA) and the US BITs, also made reference to the wording of "in like circumstances". 50 However, the challenge with an unqualified reference to "like circumstances" was that it led to inconsistent interpretations of case law. ${ }^{51}$ Indeed, the wide scope of likeness when determining "like circumstances" led to unpredictable decisions.

It is for this reason that recent treaties, such as PAIC and the 2007 COMESA Investment Agreement, include an additional criterion for the assessment of the concept of "in like circumstances". ${ }^{22}$ Likewise, the concept of "in like circumstances" under the Amended Annex requires an overall examination, on a case-by-case basis, of all circumstances of an investment, such as its effects on third persons and the local community or on the local, regional, or national environment, including cumulative effects of all investments within a jurisdiction on the environment.53 Relevant circumstances may also be the sector in which the investor is, the aim of the measure concerned, regulatory processes generally applied in relation to the measure concerned, other factors directly related to investment or to the investor in relation to the measure concerned. ${ }^{54}$

The list is non-exhaustive. However, it takes into consideration a broader view than taken by several arbitral tribunals, which found it adequate merely to enquire into whether foreign investors when compared to domestic investors are in the same business or economic sector. The Amended Annex also adds, in the same provision, a specific exception to the national treatment standard.55 Presumably, the drafters of the Amended Annex considered it to be relevant to include a specific article on exceptions to national treatment in order to give SADC member countries the possibility of pursuing national development objectives without breaching the national

48 South African Development Community https:/www.sadc.int/files/7114/9500/6315/ Agreement_Amending_Annex_1_-_Cooperation_on_investment_-_on_the_Protocol_on_ Finance_Investment_-_English_-_2016.pdf Art 6(1).

49 Ibid.

50 UNCTAD Investment Policy Hub "North American Free Trade Agreement" https://investmentpolicy.unctad.org/international-investment-agreements/treaties/otheriia/ 3104/nafta-1992- (accessed 2020-07-21) Art 1102 and Art 1103; Office of the United States Trade Representative https:/ustr.gov/sites/default/files/BIT\%20text\%20for\%20ACIEP\%20 Meeting.pdf art 3 and 4.

51 Sornarajah The International Law on Foreign Investment (2009) 206.

52 UNCTAD Investment Policy Hub "COMESA Investment Agreement" https://investmentpolicy.unctad.org/international-investment-agreements/treatyfiles/3092/download (accessed 2020-08-19) art 17(2).

53 SADC https://www.sadc.int/files/7114/9500/6315/Agreement_Amending_Annex_1_Cooperation_on_investment_-_on_the_Protocol_on_Finance_Investment_-_English_-

54 Ibid. 2016.pdf art $6(2)(a)-(f)$.

55 SADC https://www.sadc.int/files/7114/9500/6315/Agreement_Amending_Annex_1_Cooperation_on_investment_-_on_the_Protocol_on_Finance_Investment_-_English_2016.pdf art $\overline{6}(3)$. 
treatment standard. In this regard, SADC member states may, in accordance with their respective domestic legislation, "grant preferential treatment to qualifying investments and investors in order to achieve national development objectives". ${ }^{56}$

\section{THE ABSENCE OF FET AND MFN}

\section{Fair and equitable treatment}

It is well known that the majority of investment disputes under the international investment law regime are based on violation of the FET standard. ${ }^{57}$ In other words, FET is the most invoked standard in international investment arbitrations. The arbitral tribunals have interpreted the FET standard widely and with much flexibility to hold host governments responsible for violation of due process and other general principles of international law. ${ }^{58}$ The content of the standard has been developed through arbitral practice, with principal concerns that FET lacks precise content. Therefore, the tribunals have enjoyed wide discretion to interpret it broadly. 59 The question is whether FET is tied to the customary international law minimum standard. In 2001, the NAFTA Free Trade Commission "interpreted" that the fair and equitable treatment standard should be considered to be nothing more than the customary international law minimum standard. Questions have also been raised in the context of sustainable development on whether the FET standard hinders the achievement of sustainable development. This is because the standard is said to limit, more than other standards of treatment, the regulatory autonomy of the host state, especially in environmentally and socially sensitive areas. ${ }^{60}$

Various options exist in treaty drafting for resolving the challenges brought about by the FET treatment standard. They include: (1) linking the fair-andequitable standard to the customary international law minimum standard, as noted above; (2) providing an exhaustive list of obligations related to FET; (3) completely eliminating the standard of FET from the treaty; and (4) providing an alternative formulation of the FET such as fair administrative treatment. ${ }^{61}$ Given the controversy and uncertainty regarding the FET standard, current reform approaches in particular seek to draft clearer and more predictable FET provisions. For example, option 2 is contained in CETA, which provides as follows: 
"A Party breaches the obligation of fair and equitable treatment referenced in paragraph 1 if a measure or series of measures constitutes: (a) denial of justice in criminal, civil or administrative proceedings; (b) fundamental breach of due process, including a fundamental breach of transparency, in judicial and administrative proceedings; (c) manifest arbitrariness; (d) targeted discrimination on manifestly wrongful grounds, such as gender, race or religious belief; (e) abusive treatment of investors, such as coercion, duress and harassment; or ( $\mathrm{f}$ ) a breach of any further elements of the fair and equitable treatment obligation adopted by the Parties in accordance with paragraph 3 of this Article."62

This approach can arguably mitigate abuse of the FET standard in litigation by establishing, in specific terms, an exhaustive list of indicators. Similarly, the South African Protection of Investment Act, ${ }^{63}$ Brazil and the SADC Model $\mathrm{BIT}^{64}$ have adopted the fourth option with the aim of narrowing the FET standard to fair administrative processes, thereby eliminating the expansive interpretation of FET. A more radical reform approach is to avoid any inclusion of the standard in the treaty. In light of the prevailing uncertainties of interpretation and the more precise FET provisions, the drafters of the Amended Annex decided not to include the FET standard. Other new investment agreements such as PAIC and the Indian Model BIT have also done away with FET altogether. ${ }^{65}$ Therefore, it is clear from the above discussion that the FET standard poses a direct challenge to the regulatory space and its removal only heralds the reassertion of regulatory freedom. By excluding FET, a major basis for challenge to regulatory freedom is removed.

\section{Most favoured nation provision}

Under the most favoured nation (MFN) treatment, contracting states enter into a binding obligation to treat investors and their investments in their territory on a basis that is no less favourable than the treatment accorded to investments of nationals of any third states. The aim of the MFN standard is to create equal competitive conditions for all foreign investors, independent of their nationality, by creating a level playing field for all foreign investors without discrimination on the basis of nationality. 66 On the basis of an MFN provision, a foreign investor is able to invoke benefits that the host state has extended to investors from a third state. The MFN standard, however, is not without its blemishes. The scope and use of the MFN standard in international investment law has attracted significant controversy. The central issue of this controversy relates to the broad interpretation of the MFN standard and the use of this standard by foreign investors to borrow advantageous substantive and procedural provisions from third-country

62 UNCTAD Investment Policy Hub https://investmentpolicy.unctad.org/internationalinvestment-agreements/treaties/treaties-with-investment-provisions/3546/canada---eu-ceta2016- (accessed 2021-12-01).

6322 of 2015.

64 SADC https://www.iisd.org/itn/wp-content/uploads/2012/10/SADC-Model-BIT-TemplateFinal.pdf art 5.

65 Rajput 2017 Manchester Journal of International Economic Law 293.

66 Sornarajah The International Law on Foreign Investment 392. 
investment treaties to replace the provisions of the primary investment agreement such as BITs. ${ }^{67}$

Consequently, such importation from a secondary treaty undermines the originally negotiated BIT, and the political and diplomatic reasons behind negotiating BITs. However, it is obvious from the wording of the MFN provision that foreign investors can successfully import substantive and procedural protections. Indeed, there is a precedent with regard to the broad use of this standard. It has been held that it is possible for a foreign investor that is protected by an investment treaty with a most favoured nation clause to use a better dispute-settlement provision from a treaty concluded by the respondent state with a third state. States have responded to these concerns by either modifying their treaty to provide express exceptions or by completely removing the MFN provision from their investment treaties. For example, the TPP clearly provides that the MFN provision does not apply to jurisdictional matters, especially in ISDS. ${ }^{68}$ Article 8.7(4) of CETA makes it clear that the MFN provision prevents foreign investors from borrowing favourable substantive provisions from secondary BITs. ${ }^{69}$ The South African Protection of Investment $\mathrm{Act}^{70}$ completely removes the MFN provision.

Dolzer and Schreuer maintain that it is difficult to state clearly in which direction the interpretation of MFN might head in future, and especially whether MFN could be used to import provisions from agreements other than BITs (such as the WTO agreements). ${ }^{71}$ If the tribunals proceed in such a direction, it will make sizable inroads into the regulatory space. The kind of treatment standards with which the host state would have to comply would be far greater than what it negotiated in the BIT which it is facing an investment claim. The effect of a broad interpretation of MFN is that a higher mandatory framework is created with the most onerous provisions, and the host state will have to comply with that highest standard. Therefore, through MFN, a common obligation is imposed on all host states, irrespective of the terms of the underlying BIT under which the dispute arose. The addition of new treatment standards through MFN poses a threat to regulatory freedom. In White Industries $v$ India, ${ }^{72}$ the tribunal held that the Government of India was not responsible for denial of justice owing to a long delay of nine years in not enforcing the commercial arbitration award. Thereafter, the tribunal imported the standard of effective means from the India-Kuwait BIT on the ground that the India-Australia BIT had an MFN clause. This manner of invocation of the MFN clause was bound to meet with criticism. The exclusion of MFN from the Indian Model BIT is a sharp reaction to the jurisprudence on MFN and the stance of the White Industries tribunal.

67 Porterfield "The Exhaustion of Local Remedies in Investor-State Dispute Settlement: An Idea Whose Time Has Come?" 2015 Yale Journal of International Law 4.

68 UNCTAD Investment Policy Hub https://investmentpolicy.unctad.org/internationalinvestment-agreements/treaties/treaties-with-investment-provisions/3546/canada---eu-ceta2016- Art 28.

69 Office of the United States Trade Representatives https://ustr.gov/trade-agreements/freetrade-agreements/trans-pacific-partnership/tpp-full-text Art (9)(5)(3).

7022 of 2015.

71 Dolzer and Schreuer Principles of International Investment Law 211.

72 White Industries Australia Limited $v$ The Republic of India UNCITRAL, Final Award (30 November 2011) par 4.4.6. 
Therefore, based on the unintended consequences of the MFN provisions as discussed above, the MFN provision has been removed by the Amended Annex 1 of the SADC FIP. This is in line with recommendations by the South African government that the MFN clause should be removed and replaced with a more substantive national treatment provision. ${ }^{73}$ Notably, the MFN provision is also missing in the SADC Model BIT based on the consideration that the model is intended to be followed by bilateral investment treaties in SADC member states and, as such, they should not establish unintended multilateralisation through MFN provisions ${ }^{74}$ However, the exclusion of this principle from the Amended Annex is likely to cause a measure of unease among investors and indeed constitute a significant limitation because, without an MFN clause to fall back on, they will have to come to terms with the possibility that their investment will be receiving less favourable treatment compared with the investments of others. ${ }^{75} \mathrm{~A}$ better and a balanced approach is the one adopted under PAIC. PAIC provides that there is no breach of MFN treatment when an AU member state adopts measures that are "designed and applied to protect or enhance legitimate public welfare objectives, such as public health, safety and the environment". ${ }^{76}$ In addition, PAIC precludes measures that are taken by reason of "national security, public interest, and public health or public morals to be considered as a less favourable treatment" within the meaning of the MFN provision. ${ }^{77}$

\section{EXPROPRIATION CLAUSE}

Generally, the formulation of the term "expropriation" in international investment treaties includes words such as "measures tantamount" and "measures equivalent" to an expropriation. ${ }^{78}$ The expansive nature of such language is intended to cover all forms of expropriation - not just direct expropriation, which is the forceful seizure of a foreign investor's property or the transfer of legal title away from investors. The purpose is also to cover indirect expropriation, which occurs when a state takes effective control of, or otherwise interferes with the use, enjoyment or benefit of investment, strongly depreciating its economic value, even without a direct taking of property. ${ }^{79}$ The expropriation clause in IIAs is one that may limit most states' regulatory space. For this reason, it may be good to draft a detailed provision clarifying what constitutes indirect expropriation in order to provide guidance to tribunals, and to prevent expansive interpretations.

73 Parliamentary Monitoring Group http://pmg.org.za/files/150922summary.pdf (accessed 2020-09-12).

74 Art 6 of the SADC Model BIT.

75 Qumba "Safeguarding Foreign Direct Investment in South Africa: Does the Protection of Investment Act Live up to Its Name?" 2018 South African Journal of International Affairs 347.

76 African Union Commission https://au.int/sites/default/files/documents/32844-doc-draft_panafrican investment_code_december_2016 en.pdf Art 7(1).

77 African Union Commission https://au.int/sites/default/files/documents/32844-doc-draft_panafrican_investment_code_december_2016_en.pdf Art 8(2).

78 Rajput 2017 Manchester Journal of International Economic Law 297.

79 Chidede "The Right to Regulate in Africa's International Investment Law Regime" 2019 Oregan Review of International Law Regime 442. 
It is also necessary to explain the circumstances and the criteria to determine and differentiate non-compensable regulatory measures from indirect expropriation. For instance, the provision of the IISD (International Institute for Sustainable Development) Model on expropriation reiterates that regulatory measures may not be considered as expropriation. The IISD Model, under its article $8(\mathrm{I})$, stipulates that non-discriminatory regulatory measures taken by a party that are designed to protect or enhance legitimate public-welfare objectives, such as health, safety and the environment, do not constitute indirect expropriation. ${ }^{80}$ Such measures, nevertheless, are required to be consistent with the right of states to regulate and the customary international law principles on police powers. While direct expropriations have been easy to identify, indirect expropriations have been the subject of debate and discrepancy in investment tribunals as well as host states. Drawing the line between an indirect expropriation and a bona fide non-regulatory measure adopted for public interest has been, in practice, very difficult. ${ }^{81}$

In response to this problem, the 2012 US Model BIT ties the elements of "indirect expropriation" with customary international law.82 The Indian Model BIT goes a step further. It specifies the ingredients that have to be kept in mind when deciding cases on indirect expropriation. ${ }^{83}$ In addition, certain actions are excluded, such as actions taken by a government in a commercial capacity. An investor cannot claim that a loss suffered while competing with a public enterprise acting in a commercial capacity amounts to indirect expropriation. Also, non-discriminatory regulatory measures or decisions of judicial bodies to protect a legitimate public interest or purposes, such as public health, safety and the environment, would not constitute expropriation. ${ }^{84}$ These provisions directly protect legitimate regulatory exercises. This comports with the United Nations Commission on Trade and Development's recommendation on the need for precision, in which it stated that

"the expropriation clause has the potential to pose undue constraints on State's regulatory capacity. To avoid this, policy makers could clarify the notion of indirect expropriation and introduce some criteria to distinguish between indirect and legitimate regulation that does not require compensation." 85

However, the Amended Annex does not provide distinct definitions for the terms "expropriation" and "indirect expropriation", the difference between the two being a formal transfer of title and an outright seizure of property.

80 International Institute for Sustainable Development "IISD Model International Agreement on Investment for Sustainable Development" https:/www.iisd.org/publications/iisd-modelinternational-agreement-investment-sustainable-development-negotiators (accessed 202008-21) art 8(1).

81 Titi The Right to Regulate in International Investment Law (2014) 32.

82 Office of the United States Trade Representatives https://ustr.gov/sites/default/files/ BIT\%20text\%20 for\%20ACIEP\%20Meeting.pdf Art 6(1).

83 The Government of the Republic of India "Indian Model BIT" art 5(3).

84 The Government of the Republic of India "Indian Model BIT" art 5(4).

85 United Nations Commission on Trade and Development, Expropriation UNCTAD Series on International Investment Agreements https://unctad.org/system/files/officialdocument/unctaddiaeia2011d7_en.pdf (accessed 2020-08-21). 
Secondly, the provision sets out the legality requirements, which are the classic quartet that can be found in most BITs - namely, public purpose, due process of law, non-discrimination, and payment of compensation. Although the due process requirement is not common to most IIAs, all four requirements are well accepted today as the criteria for examining the legality of expropriation under international law. ${ }^{86}$ Contemporary case law indeed admits that they reflect customary international law. Most significantly, the provision requires payment of fair and equitable compensation. ${ }^{87}$ This is part of the recommendation by the South African government that the expropriation provision should be drafted in line with the now controversial section 25 of the South African Constitution, which requires that the "amount of compensation and the time and manner of payment must be just and equitable, reflecting an equitable balance between the public interests of those affected and all the relevant circumstances". 88 Consequently, the compensation provision in the amended annex has rather been drafted while keeping in mind the need to offer guidance to the arbitral tribunals that have been finding it difficult to assess the value of wrongfully expropriated properties, otherwise they would be nugatory.

The Amended Annex ${ }^{89}$ therefore dispenses with the requirement to pay prompt, adequate and effective compensation, which obviously refers to the Hull formula, named after the US Secretary of State who first used it in 1938..$^{90}$ Due to its contestation as expressed by formerly colonised states during the 1960s and 1970s, its customary value cannot be ascertained. In particular, this position was supported by the UN General Assembly Resolutions 1803 (on Permanent Sovereignty Over Natural Resources) ${ }^{91}$ and 3281 Charter of Economic Rights and Duties of States. ${ }^{92}$ Both have established that the standard of compensation has to be determined by reference to the domestic law of the expropriating state. The Amended Annex approach on determining the value of compensation has been said to reflect a proper approach for determining compensation because it strikes a balance between the public interest and the interests of those affected. ${ }^{93}$ The reason is that while there is a presumption that the fair market value will be used, a state can still rebut this presumption on the basis of the equitable criteria set out in the provision.

86 SADC https://www.sadc.int/files/7114/9500/6315/Agreement_Amending_Annex_1_Cooperation_on_investment_-_on_the_Protocol_on_Finance_Investment_-_English_-

87 Ibid 2016.pdf Art 5(1).

88 S 25(3) of the Constitution of the Republic of South Africa, 1996.

89 SADC https://www.sadc.int/files/7114/9500/6315/Agreement_Amending_Annex_1_Cooperation_on_investment_-_on_the_Protocol_on_Finance_Investment_-_English_2016.pdf Art 5(1).

90 Mendelson "Compensation for Expropriation: The Case Law" 1985 The American Journal of International Law 420.

91 General Assembly Resolution 1803 (XVII) of 14 December 1962, "Permanent Sovereignty over Natural Resources" https://www.ohchr.org/Documents/Professionallnterest/ resources.pdf (accessed 2020-08-23).

92 United Nations General Assembly "Charter of Economic Rights and Duties of States" https://www.aaas.org/sites/default/files/SRHRL/PDF/IHRDArticle15/Charter_of_Economic_ Rights_and_Duties_of_States_Eng.pdf (accessed 2020-08-23).

93 Kondo 2017 Potchefstroom Electronic Law Journal 15. 
Secondly, the Amended Annex provides for the manner in which the compensation must be given. It states that the payment shall be made in a freely convertible currency in accordance with the applicable law of the host state. ${ }^{94}$ Thirdly, the investor is given a right under domestic law to challenge the expropriation, or the valuation of the compensation awarded. This can be done by means of a judicial review or by means of an independent authority. This ensures that an investor's rights to fair administrative action are realised. Fourthly, and more interestingly, the Amended Annex notes that where a payment is significantly burdensome on a host state, such a state may pay the amount due yearly over a 3-year period. Alternatively, the investor and the host state may agree on a suitable period and interest rate. The option to stagger the payment for expropriation or nationalisation is crucial in the developing country context, where resources may not always be available to immediately provide for compensation. Lastly, the 2016 SADC FIP addresses the issue of indirect expropriation. It provides that where a host state undertakes a measure of general application:

"that is designed and applied to protect and enhance legitimate public welfare objectives, such as public health, safety and the environment, it shall not constitute indirect expropriation." 95

This is important because it reinforces the crucial right to regulate, which is discussed under the next heading. Furthermore, it protects the host state from frivolous and litigious suits related to the indirect expropriation of investments owing to a domestic measure.

\section{RIGHT TO REGULATE}

The right to regulate as a concept in international investment law is a legal right, exceptionally permitting the host state to regulate in derogation of international commitments it has undertaken by means of an investment agreement without incurring a duty to compensate. ${ }^{96}$ This definition focuses on international investment law as a public international law discipline, with reference to investment treaties as opposed to investment contracts. It is now beyond doubt that governments retain their right to regulate within their borders under public international law. However, when an exercise of this broad public-international-law right to regulate breaches investment treaty provisions, a state becomes liable towards an investor and compensation is generally due. The dilemma that has emerged under international investment law is how to exercise the right to regulate without incurring the duty to compensate adversely affected investors. ${ }^{97}$ While a state has a right

94 SADC https://www.sadc.int/files/7114/9500/6315/Agreement_Amending_Annex_1__Cooperation_on_investment_-_on_the_Protocol_on_Finance_Investment_-_English_2016.pdf art 5(3).

95 SADC https://www.sadc.int/files/7114/9500/6315/Agreement_Amending_Annex_1__Cooperation_on_investment_-_on_the_Protocol_on_Finance_Investment_-_English_2016.pdf art 5(7).

96 Henckels "Indirect Expropriation and the Right to Regulate: Revising Proportionality Analysis and the Standard of Review in Investor-State" 2012 Journal of International Economic Law 225.

97 Korzun "The Right to Regulate in Investor-State Arbitration: Slicing and Dicing Regulatory Carve-Outs" 2017 Vanderbilt Journal of Transnational Law 368. 
to regulate, the exercise of this right comes with the concomitant responsibility to compensate an affected investor where such a measure leads to indirect expropriation. ${ }^{98}$ The Amended Annex elaborates more comprehensively than the original Annex on provisions regarding each host state's right to regulate with respect to domestic health, safety and environmental protection. Article 11 of the Amended Annex stipulates:

"State parties recognise that it is inappropriate to encourage investment by relaxing domestic health, safety and environmental measures and agree not to waive or otherwise derogate from, international treaties they have ratified, or offer to waive or otherwise derogate from, such measures as an encouragement for the establishment, acquisition, expansion or retention in their territories, of an investment." 99

This provision reiterates state parties' international obligations on the protection of health, safety and environmental standards. The right of a host state to adopt environmental measures has increasingly become part of modern IIA practice, and most treaties contain provisions specifically addressing the relationship between investment and the environment. ${ }^{100}$ The non-lowering of standards is inserted to prevent race-to-the-bottom actions by host states in a bid to lure investments. Measures directed at environmental protection in IIAs guarantee a host state's right to regulate in the field of environment. In addition, the Amended Annex preserves the right of host states to take regulatory measures to ensure that development in their territory is consistent with sustainable development and legitimate social and economic policy objectives. In particular, article 12 provides:

"(1) In accordance with customary international law and other general principles of international law, the Host State has the right to take regulatory or other measures to ensure that development in its territory is consistent with the goals and principles of sustainable development, and with other legitimate social and economic objectives.

(2) Except where the rights of a Host State are expressly stated as an exception to the obligations of this Annex, a Host State's pursuit of its rights to regulate shall be understood as embodied within a balance of the rights and obligations of investors and investments and Host States, as set out in this Annex.

(3) Non-discriminatory measures taken by a State Party to comply with its international obligations under other treaties shall not constitute a breach of this Annex."

It is clear from the reading of these provisions in the Amended Annex that SADC host states preserve the right to regulate investments in accordance with their sustainable development goals and in line with customary international law and other general principles of international law. This is contrary to the 2006 Annex, which merely provided that a state party has the

"right to regulate in the public interest and to adopt, maintain or enforce any measure that it considers appropriate to ensure that investment activity is

98 Titi The Right to Regulate in International Investment Law (2014) 34.

99 SADC https://www.sadc.int/files/7114/9500/6315/Agreement_Amending_Annex_1_CCooperation_on_investment_-_on_the_Protocol_on_Finance_Investment_-_English_2016.pdf art 5(7).

100 Subedi International Investment Law Reconciling Policy and Principle (2020) 78. 
undertaken in a manner sensitive to health, safety or environmental concerns." 101

These kinds of provision establish vague standards capable of broad interpretation. The Amended Annex further requires the host states to balance their regulatory autonomy with the rights and obligations of investors provided under the SADC FIP. ${ }^{102}$

Furthermore, it provides that "non-discriminatory measures taken by a state party to comply with its international obligations under other treaties shall not constitute a breach of this Annex". This provision aligns with the language in CETA, which specifies that the fact that a party regulates (such as by modifying its laws in a manner that negatively affects an investment) or that a party interferes with an investor's legitimate expectations, does not, by itself, mean that such regulation or interference amounts to a violation of the treaty's section on investment protection. ${ }^{103}$ The Indian Model BITs contain a similar clause providing that non-discriminatory, regulatory measures or decisions of judicial bodies to protect issues of legitimate public interest or purposes such as public health, safety and the environment would not constitute expropriation. ${ }^{104}$ These provisions directly protect the legitimate exercise of regulatory powers.

\section{INVESTOR OBLIGATIONS}

The majority of traditional IIAs impose reciprocal obligations on contracting state parties and do not impose direct legal obligations on investors in terms of international law principles regarding their business conduct. Consequently, in the traditional BITs there was no balance between investors' rights and obligations and those of the contracting states under international investment law. Recently, the inclusion of direct obligations for investors has gained traction and real recognition under investment treaty practice. The prospect of significant change to the current IIA regime is a reality. Reform of ISDS, as well as rebalancing and recalibration of investment obligations, are on the agenda of many states, including notably the European Union as it moves towards creating a new generation of EU investment agreements. ${ }^{105}$ More recent treaties have included, for instance, the obligation of foreign investors to comply with all applicable domestic law

101 Zamir and Barker "The Trans-Pacific Partnership Agreement and States Right to Regulate Under International Investment Law" 2017 Denver Journal of International Law and Policy 215.

102 SADC https://www.sadc.int/files/7114/9500/6315/Agreement_Amending_Annex_1__Cooperation_on_investment_-_on_the_Protocol_on_Finance_Investment_-_English_2016.pdf Art 12.

103 UNCTAD Investment Policy Hub https://investmentpolicy.unctad.org/internationalinvestment-agreements/treaties/treaties-with-investment-provisions/3546/canada---eu-ceta2016- Article 8(10).

104 The Government of the Republic of India "Indian Model BITs" art 5(5).

105 Bjorklund and Marcoux "Foreign Investor's Responsibilities and Contributory Fault in Investment Arbitration" 2020 International \& Comparative Law Quarterly 878. 
and measures of the host state, or to accord priority to workers coming from the concerned state, provided they have the same qualifications. ${ }^{106}$

In light of the asymmetrical structure of most IIAs, which impose legal obligations on host states but not on foreign investors, host states have generally raised investor wrongdoing primarily as a defence against an investor's claim, although a few cases have involved counterclaims by host states. The final award in Al-Warraq $v$ Indonesia ${ }^{107}$ contributes to and develops this jurisprudence. The tribunal stated that article 9 of the Agreement on Promotion, Protection and Guarantee of Investments among members of the Organisation of the Islamic Conference ${ }^{108}$ imposes a positive obligation on investors to respect the law of the host state, as well as public order and morals. An investor, of course, has a general obligation to obey the law of the host state, but article 9 raises this obligation from the plane of domestic law (and jurisdiction of domestic tribunals) to a treaty obligation binding on the investor in an investor-state arbitration. An analogy can be drawn with a so-called "umbrella clause" that elevates contractual obligations to the treaty plane. The fact that the contracting parties imposed treaty obligations on investors (which the claimant assented to by accepting the open offer of investment arbitration made by the respondent in the Organisation of Islamic Conference (OIC) agreement) confirms the interpretation of article 17 of the Agreement on Promotion, Protection and Guarantee of Investments among members of the Organisation of the Islamic Conference that permits counterclaims by the respondent state. Although the Al Warraq decision can be criticised for failing to consider the status and content of the "clean hands" doctrine, the final award is important in solidifying a jurisprudential trend in which investor-state tribunals find that an investor may be liable.

In addition, the IISD was first to adopt an alternative approach in its 2006 Model Investment Agreement. ${ }^{109}$ Within the African continent, as part of the latest round of negotiations on the UN Binding Treaty on transnational corporations and other business enterprises with respect to human rights, African civil society organisations are calling for a treaty that reflects African perspectives and effectively addresses African experiences. ${ }^{110}$ This is because over the last few decades, the continent has witnessed an increased involvement of foreign and local investors in massive human rights abuses and violations, sometimes with the implicit backing of the host state. These investments, often by large and economically powerful transnational corporations, have a long history of profiting from human rights

106 UNCTAD Investment Policy Hub https://investmentpolicy.unctad.org/internationalinvestment-agreements/treaty-files/5409/download Art 24.

107 Hesham T. M AL Warraq $v$ Republic of Indonesia, UNCITRAL.

108 Art 9 of the Agreement on Promotion, Protection and Guarantee of Investments among members of the Organisation of the Islamic Conference https://www.italaw.com/sites/default/files/laws/italaw6203.pdf (accessed 2021-12-01).

109 IISD Model "International Agreement on Investment for Sustainable Development" https://www.iisd.org/system/files/publications/investment_model_int_handbook.pdf (accessed-2020-08-23).

110 Bruce "African Organisation Push for a Legally Binding Treaty" https://www.wits.ac.za/news/sources/cals-news/2020/african-organisations-push-for-alegally-binding-treaty.html (accessed 2020-08-23). 
abuses and environmental destruction, especially in countries that may have weaker laws and depend on foreign investment. Unfortunately, it remains difficult to hold them accountable for their actions, owing to the huge power imbalances that exist between states, corporations and communities. The few attempts to address this, like the UN Guiding Principles on Business and Human Rights, have been voluntary and ineffective. ${ }^{111}$

The Amended Annex specifically provides for a clause dealing with investor responsibility. ${ }^{112}$ It requires that investors and their investments abide by the laws, regulations, administrative guidelines and policies of the host state for the full cycle of the investment. The challenge with this provision is that it focuses on compliance with domestic laws and procedures but does not require the investor or the investment to comply with international standards or to participate in international bodies, as is required by the corporate social responsibility (CSR) clause in PAIC, for example. ${ }^{113}$ It is therefore important to clarify the corporate responsibility clause in the SADC FIP so as to shift its emphasis from the current specific compliance with law and policy to a broader and more general compliance.

Moreover, there is also a key personnel provision under the Amended Annex, which is a critical provision on how a foreign company will fill important vacancies such as managerial positions within their company structures. This is because foreign companies often look to bring in expatriates to take up positions requiring special skills. This provision is expressed differently in investment treaties. Some of its forms include entry and sojourn, key personnel, permits, and the sourcing of requisite skills. The provision states that state parties shall, subject to their national laws and regulations, permit investors to engage key personnel and other necessary human resources of their choice, regardless of their nationality, under the following circumstances:

"(a) where the skills do not exist in the Host State and the Region,

(b) where State Parties are satisfied that the sourcing of such skills will be in compliance with regional policies; and

(c) where such sourcing would enhance the development of local capacity through skills transfer." 114

While this provision is partially protectionist, it supports the domestic policies of SADC member states. Most countries now seek to ensure that investments benefit their citizens through employment and, as a result, they want to ensure that investors bring in only specialised employees who will transfer their skills to locals. As far as the use of natural resources is

111 United Nations Human Rights office of the High Commissioner "The U.N. Guiding Principles on Business and Human Rights" https://www.ohchr.org/documents/publications/ guidingprinciplesbusinesshr_en.pdf (accessed 2020-08-24).

112 SADC https://www.sadc.int/files/7114/9500/6315/Agreement_Amending_Annex_1__Cooperation_on_investment_-_on_the_Protocol_on_Finance_Investment_-_English_2016.pdf Art 8.

113 African Union Commission https://au.int/sites/default/files/documents/32844-doc-draft_panafrican_investment_code_december_2016_en.pdf art 22.

114 SADC https://www.sadc.int/files/7114/9500/6315/Agreement_Amending_Annex_1__Cooperation_on_investment_-_on_the_Protocol_on_Finance_Investment_-_English_2016.pdf Art 9 . 
concerned, the Amended Annex imposes an obligation on state parties to promote the use of their natural resources in a sustainable and environmentally friendly manner. ${ }^{115}$ For developing countries, the provision is key to ensuring that resources are used optimally. Considering this context, it can be argued that this provision should impose responsibility also on investors, not just on the State. The investor should be held to a standard of responsibility not to exploit or use natural resources to the detriment of the rights and interests of the host state and to respect the rights of the local population as well as avoid land-grabbing practices vis-à-vis local communities. For instance, the obligations on the use of natural resources under PAIC are as follows:

"1. Investors shall not exploit or use local natural resources to the detriment of the rights and interests of the host State.

2. Investors shall respect rights of local populations and avoid land grabbing practices vis-à-vis local communities."116

While international investment law was traditionally not concerned with the conservation of natural resources, issues of environmental protection and the social well-being of a host state's population directly relate to most investment operations in a host country. Today, the perception has changed, and sustainable development objectives have become recognised guiding principles for developing and developed states. In recent treaty practice, societal concerns have prudently been introduced into IIAs. ${ }^{117}$ However, according to UNCTAD, there is still the need to harmonise new IIAs with the broader common concerns of society. ${ }^{118}$ Therefore, the provisions that promote sustainable development, investor responsibility, protection of the environment, health, human rights and conservation of natural resources should be imposed on both host governments and investors alike. Finally, the Amended Annex also contains a "non-lowering of standards" clause that states that any relaxation of domestic health, safety and environmental legislation in order to attract investments is prohibited. ${ }^{119}$ By comparison, PAIC also contains a specific chapter on the direct obligations of investors, counterbalancing the chapter on the guarantees of treatment for investors and investments. The chapter on investors' obligations contains six provisions entitled: (1) framework for corporate governance; (2) sociopolitical obligations; (3) bribery; (4) corporate social responsibilities; (5) obligations as to the use of natural resources; and (6) business ethics and human rights. ${ }^{120}$

115 SADC https://www.sadc.int/files/7114/9500/6315/Agreement_Amending_Annex_1__Cooperation_on_investment_-_on_the_Protocol_on_Finance_Investment_-_English_2016.pdf art 10 .

116 African Union Commission https://au.int/sites/default/files/documents/32844-doc-draft_panafrican_investment_code_december_2016_en.pdf art 23.

117 Mbengue and Schacherer 2017 The Journal of World Investment and Trade 415.

118 UNCTAD "International Investment Agreements Flexibility for Development" https://unctad.org/system/files/official-document/psiteiitd18.en.pdf (accessed 2020-08-24).

119 SADC https://www.sadc.int/files/7114/9500/6315/Agreement_Amending_Annex_1__Cooperation_on_investment_-_on_the_Protocol_on_Finance_Investment_-_English_2016.pdf art 11 .

120 African Union Commission https://au.int/sites/default/files/documents/32844-doc-draft_panafrican_investment_code_december_2016_en.pdf art 24. 


\section{FULL PROTECTION AND SECURITY (FPS)}

Full protection and security, or constant protection and security, is a standard that is present in most investment treaties, next to the fair and equitable treatment standard, which it complements. Full protection and security has been interpreted to involve the obligation of the State to act in order to protect an investment from adverse effects that stem from the State's own actions or from those of private parties. ${ }^{121}$ However, like other investment standards, the interpretation of full protection and security is not free of controversy. In particular, some debate still exists regarding two topics: the first concerns the question of whether the standard covers not only physical but also legal security; and the second concerns whether the standard is linked to the customary international law minimum standard or whether it stands independently. ${ }^{122}$ These two questions are linked inasmuch as it is unclear whether an unqualified full protection and security standard, if equated to the minimum standard under customary international law, may be construed not to extend beyond physical security.

In the context of NAFTA, as in treaties concluded on the basis of the post2004 US and Canadian model BITs, the issue is settled. Where the standard is unqualified, tribunals have followed various approaches, sometimes determining that full protection and security is no more than the customary international law standard of the treatment of aliens, despite the absence of an explicit limitation to this effect. An example of this strain of arbitral jurisprudence is the El Paso case, adjudicated on the basis of the 1991 USArgentina BIT. ${ }^{123}$ Full protection and security has sometimes been construed to offer protection beyond mere physical security - and especially it has been considered to include legal protection. Here again, the jurisprudence has not been consistent, since other tribunals have been reluctant to recognise protection beyond physical security (although sometimes in obiter dicta). There is already evidence from the Vivendi tribunal that the full protection and security standard would naturally be limited to physical protection if the parties had clearly stated so in the BIT. ${ }^{124}$ Treaties such as the US Model BIT refer to protection equivalent to "the level of police protection required under customary international law". ${ }^{125}$

Many African countries have been confronted with civil strife and internal conflicts over the past decades and, as a consequence, the FPS standard, especially the protection against destruction of physical property, has a practical significance in claims against African states. The relevant example is the case of Wena Hotels $v$ Arab Republic of Egypt, ${ }^{126}$ a dispute that arose out of two long-term agreements between Wena Hotels Limited (Wena) (a

21 Qumba 2018 South African Journal of International Affairs 348.

122 Qumba 2018 South African Journal of International Affairs 349.

123 El Paso Energy International Company v Argentine Republic ICSID Case No. ARB/03/15.

124 Compañía de Aguas del Aconquija S.A. and Vivendi Universal S.A. (formerly Compañía de Aguas del Aconquija, S.A. and Compagnie Générale des Eaux v Argentine Republic ICSID Case No. ARB/97/3).

125 United States Office of the Trade Representative "US Model BIT" https://ustr.gov/sites/default/files/BIT\%20text\%20 for\%20ACIEP\%20Meeting.pdf art 5(2)(b) 2012.

126 Wena Hotels $v$ Arab Republic of Egypt ICSID Case No. ARB /98/4 par 5. 
British investor) and the Egyptian Hotels Company (EHC) to lease, operate and manage two hotels in Egypt. EHC was wholly owned by the Egyptian government. Shortly after the signing of the agreement, Wena alleged that the condition of the hotels was far below that agreed in the lease. Wena therefore withheld part of the rent under the terms of the lease. Owing to the non-payment, EHC threatened to repossess the hotels through force. Wena informed the Egyptian Minister of Tourism about this situation but there was no resolution. Witnesses reported that one night more than one hundred EHC personnel stormed the two hotels, and threatened and physically attacked the hotels' employees and guests. They were also reported to have removed a number of the hotels' belongings. The International Centre for Settlement of Investment Disputes (ICSID) arbitral tribunal found, inter alia, that there had been a breach of the protection and security standard under the UK-Egypt Treaty.

Based on the above discussion on the FPS standard of protection, it is important to note that African states have been confronted with claims by investors for physical security damage to their investments caused during conflict that destroys investors' property. ${ }^{127}$ Therefore, it is precisely in view of the many internal conflicts, destructive protests and civil upheavals that have characterised African states that the removal of the FPS clause under the Amended Annex was ill-advised. The application and respect for the FPS in African countries is relevant under the circumstances. Considering the issue of availability of resources, as discussed in tribunal decisions above, and in arguments against the protection of investment when caused by strife and violent protest in the host state, it can be concluded that the current practice and interpretation of this standard is not unreasonable. One may wonder why section 9 of the South African Protection of Investment Act $^{128}$ did not inspire the drafting of this provision. Section 9 provides:

"The Republic must accord foreign investors and their investments a level of physical security as may be generally provided to domestic investors in accordance with minimum standards of customary international law and subject to available resources and capacity."

The adoption of this provision could have provided a better balance rather than completely removing the provision.

\section{TRANSFER OF FUNDS}

The vast majority of modern IIAs contain a provision on the transfer of funds. However, investment treaties are drafted in different ways. They often deal with three basic issues: the type of payment that is covered by the right to make transfers, the issue of convertibility and exchange rates, and limitations on free transfer. The question of free transfer of funds presents a conflict between the interests of host states and those of foreign investors. For the foreign investor, the transfer of funds such as capital and profits into the home state characterises the main purpose of the business of

27 Qumba 2018 South African Journal of International Affairs 392.

12822 of 2015. 
investment. ${ }^{129}$ By contrast, many host governments seek to administer their currency and foreign reserves, which means large currency transfers into and out of the host states need to be controlled and monitored in order to protect national policies.

Unlike the old-generation BITs, recent treaty practice shows that completely free and unlimited transfer of funds is rare in the newer generation of IIAs. Current treaty drafting contains limitations on the free transfer of funds. A notable exception is the Germany Model BIT, which contains an absolutely free transfer of funds clause. ${ }^{130}$ Under newer IIAs, provisions on the transfer of funds are typically subjected to regulations and laws of the host governments relating, among other things, to insolvency, bankruptcy, criminal and penal offences, ensuring compliance with judgments and orders of administrative or judicial proceedings. ${ }^{131}$ A majority of IIAs impose restrictions on the movement of capital during periods when host governments are facing balance-of-payment problems. For example, PAIC provides first that restrictions can be adopted provided that they are in accordance with taxation as well as financial laws and regulations of the concerned member state. ${ }^{132}$

Secondly, AU member states can prevent a transfer in a nondiscriminatory manner and in accordance with its laws and regulations relating to bankruptcy, insolvency or other legal proceedings to protect the rights of creditors, address criminal or administrative violations or ensure the satisfaction of judgments in adjudication proceedings. ${ }^{133}$ Thirdly, PAIC foresees the possibility of $\mathrm{AU}$ member states adopting or maintaining measures in the event of serious balance-of-payments and external financial difficulties or the threat thereof, as well as in cases where movements of capital cause or threaten to cause serious difficulties for macroeconomic management - in particular, monetary and exchange rate policies. ${ }^{134}$ South Africa's Protection of Investment Act now briefly stipulates as follows:

"A foreign investor may, in respect of an investment, repatriate funds subject to taxation and other applicable legislation." 135

Similarly, the Amended Annex recognises that investors are allowed to repatriate their investments and returns. However, such repatriation is subject to restrictions such as rules and regulations stipulated by the host state. Another novel provision is a possible exception to the guarantee of

129 Kondo 2017 Potchefstroom Electronic Law Journal 9.

130 UNCTAD Investment Policy Hub "German Model Treaty" https://investmentpolicy.unctad.org/international-investment-agreements/treatyfiles/2865/download (accessed 2020-08-24) Art 6.

131 UNCTAD Investment Policy Hub https://investmentpolicy.unctad.org/internationalinvestment-agreements/treaty-files/5409/download art 11(2).

132 African Union Commission https://au.int/sites/default/files/documents/32844-doc-draft_panafrican_investment_code december_2016 en.pdf art 15.

133 African Union Commission https://au.int/sites/default/files/documents/32844-doc-draft_panafrican_investment_code_december_2016_en.pdf art 16(3)(a).

134 African Union Commission https://au.int/sites/default/files/documents/32844-doc-draft_panafrican investment code december 2016 en.pdf art 16(4)(a).

$135 \mathrm{~S} 11$ of the Protection of Investment Act 22 of 2015. 
free transfer of funds as indicated in article 13(2). ${ }^{136}$ Under this provision, the drafters of the Amended Annex considered it relevant for SADC member states to have a safeguard provision to respond to emergency problems first before they could allow investors to repatriate their funds. First, restrictive measures can be adopted, provided they are in line with the laws and regulations of member states. Secondly, SADC member states foresee the possibility of a state party to the Amended Annex adopting restrictive measures in the event of serious balance-of-payment problems, external financial difficulties and macroeconomic management problems, including monetary policy or exchange rate policy. While the inclusion of a list of what qualifies as an economic constraint grants a state party the leeway to use domestic laws and policy to counter tough macro-economic challenges by restricting the transfer of funds in order to facilitate sustainable economic development, it is argued that the provision could also be abused by the same host state.

\section{DISPUTE RESOLUTION MECHANISMS}

Over the last few years, ISDS has become extremely controversial and probably constitutes the most controversial issue in today's investment reform debate. Controversies regarding the utility of ISDS mechanisms reached another level in July 2017 when member states of the United Nations Commission on International Trade Law (UNCITRAL) entrusted its Working Group III with a broad mandate to work on the reform of ISDS. As can be observed in the discussions that have taken place so far in Working Group III, the legitimacy crisis faced by ISDS is multi-faceted and has dimensions ranging, among others, from the perceived length and cost of investment arbitration, and the inadequacy of ad hoc adjudication bodies to ensure consistency in the interpretation of treaties, to the perceived lack of impartiality and independence of investment arbitrators, as well as so-called third-party funding; mass actions, as well as class actions, are considered extremely problematic developments in international investment protection. It must be noted, however, that the debate in the UNCITRAL Working Group III negotiation process about a state's right to regulate and ISDS has brought some concerns back to the policy agenda. ${ }^{137}$ However, the discussions that focus on the resolution of disputes (ISDS) as opposed to background rules on foreign direct investment (FDI) from a development perspective remove significant issues from the policy agenda. IIAs and ISDS are relevant not only for what they do but also for how they have reshaped the debate; attention has shifted away from a development-oriented and holistic perspective of FDI governance.

As a result of the legitimacy crisis facing ISDS, both developed and emerging economies are currently re-evaluating their approaches to investor-state dispute mechanisms through various institutional reform approaches as well as IIAs including BITs and the investment chapters of

136 African Union Commission https://au.int/sites/default/files/documents/32844-doc-draft_panafrican_investment_code_december_2016_en.pdf art 13(2).

137 United Nations Commission on International Trade Law (UNCITRAL) "Working Group III: Investor-State Dispute Reform" https:/uncitral.un.org/en/working_groups/3/investor-state (accessed 2020-08-22). 
free trade agreements. It is well known that South Africa, for instance, has a clear policy against ISDS. The country recently reviewed all of its IIAs and terminated most of them. The law that is applicable to foreign investors in South Africa is the Protection of Investment Act, which does not contain ISDS. ${ }^{138}$ Article 25 of the Amended Annex maintains access to domestic courts and tribunals for investors. However, article 26 makes a hard exit from investor-state arbitration. It provides that any dispute between state parties will be resolved in the manner provided for under the Protocol of the Tribunal. Effectively, this means that the 2016 SADC FIP deals with statestate arbitration only. ${ }^{139}$ This is in line with the proposal by South Africa that article 28 of the 2006 SADC FIP be removed as a result of concerns with the settlement of investor-state disputes by international tribunals. Although South Africa is the only country in the SADC region that rejects ISDS, the 2016 SADC FIP shows clear signs of a growing dissatisfaction with this ISDS mechanism. ${ }^{140}$

Therefore, the 2016 SADC FIP surprisingly maintains the defunct SADC Tribunal, despite that body's questionable legitimacy. Following the matter of Mike Campbell $v$ Republic of Zimbabwe, ${ }^{141}$ the SADC Tribunal suffered a blow to its integrity, and in effect became toothless. In this case, the Tribunal found Zimbabwe's chaotic and violent land reform programme to be contrary to several SADC Treaty provisions. It thereafter ordered the Zimbabwean government to protect the right to property in relation to the farms that had not been expropriated and to pay compensation to those whose farms had been expropriated. ${ }^{142}$ The Zimbabwean government defied this ruling. The non-compliance was referred to the Summit. Zimbabwe failed to comply with the SADC Tribunal's judgments, even after the successful litigants sought and obtained orders from the Tribunal to enable the SADC Summit to compel compliance by Zimbabwe.

Instead of the SADC Summit acting to ensure that Zimbabwe complied with the SADC Tribunal judgments, it sided with Zimbabwe, which had begun a diplomatic attack on the Tribunal, employing very weak legal arguments alleging that the SADC Tribunal was not lawfully established owing to the non-ratification of the 2000 Tribunal Protocol. ${ }^{143}$ Furthermore, Zimbabwe claimed that the SADC Tribunal did not have jurisdiction to determine human rights issues. The Summit eventually decided not to reappoint those members of the Tribunal (the judges) whose terms of office were ending in 2010 and not to replace those whose terms of office would end in 2011. The Summit also directed the Tribunal not to receive any new cases pending a review of the Tribunal's "terms of reference". These developments effectively meant that the SADC Tribunal was emasculated and could not operate. In the words of one scholar, the Tribunal was

$138 \mathrm{~S} 13$ of the Protection of investment Act 22 of 2015

139 SADC https://www.sadc.int/files/7114/9500/6315/Agreement_Amending_Annex_1_Cooperation on investment - on the Protocol on Finance Investment - English 2016.pdf Art 26.

140 Kondo 2017 Potchefstroom Electronic Law Journal 29.

141 Qumba 2018 South African Journal of International Affairs 392.

142 Qumba 2018 South African Journal of International Affairs 233.

143 Qumba 2018 South African Journal of International Affairs 234. 


\begin{abstract}
"disbanded". ${ }^{144}$ All this - the non-renewal of the judges' terms of office, the non-appointment of their replacements, and the directive not to receive new cases - had no basis in the SADC Treaty and the 2000 Tribunal Protocol, and was therefore unlawful. ${ }^{145}$ SADC member states also regulate foreign investments through their internal laws. Therefore, there are two conflicting layers of laws that regulate foreign investments in SADC. Furthermore, SADC member states are parties to $127 \mathrm{BITs}$, the majority of which provide for ISDS. Therefore, ISDS is very much alive in SADC, despite SADC's repeal of the 2006 Annex 1. At the super-regional level, the newly formed COMESA-EAC-SADC Tripartite Free Trade Area (T-FTA) agreement of 2015 is entitled to have its investment protocol. ${ }^{146}$ However, the T-FTA agreement is not yet fully ratified, and there is no draft investment protocol in sight.
\end{abstract}

However, the Amended Annex is unlikely to be the last instrument that will regulate foreign investments in SADC, owing to the formation of the Tripartite Free Trade Area (T-FTA) and the African Continental Free Trade Agreement (AfCFTA). The T-FTA Agreement was concluded in Egypt on 15 June 2015, while the AfCFTA Agreement was signed in Rwanda on 21 March 2018. The T-FTA is supposed to have its own investment protocol, while the AfCFTA Agreement also provides for the conclusion of an investment protocol by 2020. This means that SADC faces the loss of regulatory authority over foreign investments. The position of PAIC, with regard to ISDS, shows that some AU member states want to provide ISDS for their investors, while others, including SADC member states, do not. It is, therefore, possible that ISDS may return to SADC via the AfCFTA investment protocol or T-FTA investment protocol. The legality of the measure of the host state under international law is a distinct aspect from access to dispute resolution. If access to dispute resolution is limited, then the violation of substantive provisions becomes academic. Procedural obstacles to access judicial settlement would reduce the enthusiasm of the foreign investor to pursue the remedy. The procedural challenges, along with the loss of investor enthusiasm, would reduce potential challenges to the actions of the host state and would have the effect of allowing several regulatory measures to go unchallenged. Access to investment arbitration is then limited to violations of treatment standards. Thus, the possibility of using MFN to expand the scope of the BIT is excluded.

SADC can learn the following lessons from the Investment Court System (ICS)proposal, the Brazilian Agreement on Cooperation and Facilitation of Investments (ACFI) and the India Model BIT. These lessons may be useful to SADC as it prepares for negotiations on the regulation of foreign investments at CFTA, T-FTA or other levels. The Brazilian ACFI provides an alternative to the traditional options of ISDS or local courts. It shows that ISDS and litigation before the courts of host states are not the only options

4 Kondo 2017 Potchefstroom Electronic Law Journal 29.

145 Phooko "The Revival of the SADC Tribunal by South African Courts: AContextual Analysis of the Decision of the South African Constitutional Court" 2019 Dejure Law Journal 421.

146 Ngobeni "The African Justice Scoreboard: A Proposal to Address Rule of Law Challenges in the Resolution of Investor-State Dispute in the Southern African Development Community" 2019 The Comparative and International Law Journal of Southern Africa 8. 
available for the resolution of investor-state disputes. ${ }^{147}$ SADC can learn to use state-state consultations in the form of preventative alternative dispute resolution (ADR). The India Model BIT provides a pro-state lesson in the tightening of foreign investment regulation with a view to maximising regulatory space for host states. The India Model BIT directs that contractual disputes have to be submitted before domestic courts. A foreign investor is barred from instituting arbitration if the investor has indulged in fraud, misrepresentation, concealment, corruption, money laundering or conduct amounting to an abuse of process. The India Model BIT also offers good lessons in the management of treaty and forum shopping, and the denial of benefits to corrupt investors. Furthermore, the India Model BIT shows that ADR can be a useful tool in the resolution of investor-state disputes, whether as a prelude to ISDS or not. Indeed, ADR is important, both prior to commencement of ISDS or litigation, and thereafter. Although making ADR mandatory will increase legal costs, in the long term it will inculcate a culture that promotes the settlement of disputes rather than the invoking of ISDS or litigation. ${ }^{148}$

\section{CONCLUSION}

Over the years, investor protection in Africa has become a necessity, yet challenging and controversial. It is a necessity because of the undeveloped adjudication practices that create uncertainties and multiple concerns relating to the pre-existing justice system's efficiency, fairness and effectiveness. It is challenging because of the legitimacy concerns that suggest a pro-investor posture. The Amended SADC FIP is characterised by challenges and controversies in the areas otherwise deemed settled in international investment law - namely, FET, MFN, FPS and ISDS. However, the bottom line is that IIL is all about balancing the somewhat conflicting interests of investors and host states. It is hard to imagine the end of this tension, especially in Africa. As shown in the analysis of this article, PAIC is intended to be a balanced model treaty, meaning it seeks a balance between investment protection and non-investment-related public interests. The drafters of PAIC did not underrate the need to attract foreign capital into Africa; yet recognised that this need should not neutralise the long-term goal of sustainable development.

Consequently, sustainable development plays a prominent role throughout PAIC. However, with the Amended Annex, the pendulum has swung decisively in favour of SADC host states in the substantive content of investment provisions. There is no doubt that in recent treaty drafting, there is a trend to create a balanced approach in the provisions of treaties. While the balancing of investor interests and public interests is a legitimate public interest exercise, it is argued that the Amended Annex drastically reduces the investor's substantive and procedural rights. By excluding provisions such as MFN, FPS and FET, the Amended Annex has not been able to reconcile and balance the interests of foreign investors with the host states' right to regulate. The exclusion of these provisions defeats the objective of

147 Ngobeni 2019 The Comparative and International Law Journal of Southern Africa 15.

148 The Government of the Republic of India "Indian Model BIT" art 15. 
this treaty, which is to achieve a balance in the amendment of the SADC FIP. Furthermore, a flat rejection of the investor-state dispute mechanism and its replacement with the defunct SADC Tribunal completely undermines the legal protection of foreign investors. It is argued that the current concerns over investor-state dispute arbitrations could have been addressed by introducing appropriate provisions dealing with the requirements to exhaust local remedies, fork-in-the-road clauses, provisions dealing with the transparency of investment dispute counterclaims and so on. Given the history of expropriation in countries in the SADC region, the flat rejection of the investor-state dispute arbitration system may prove counter-productive and drastically erode the protection of foreign investors and can potentially discourage desirable foreign investment. 